\title{
Figure S9
}
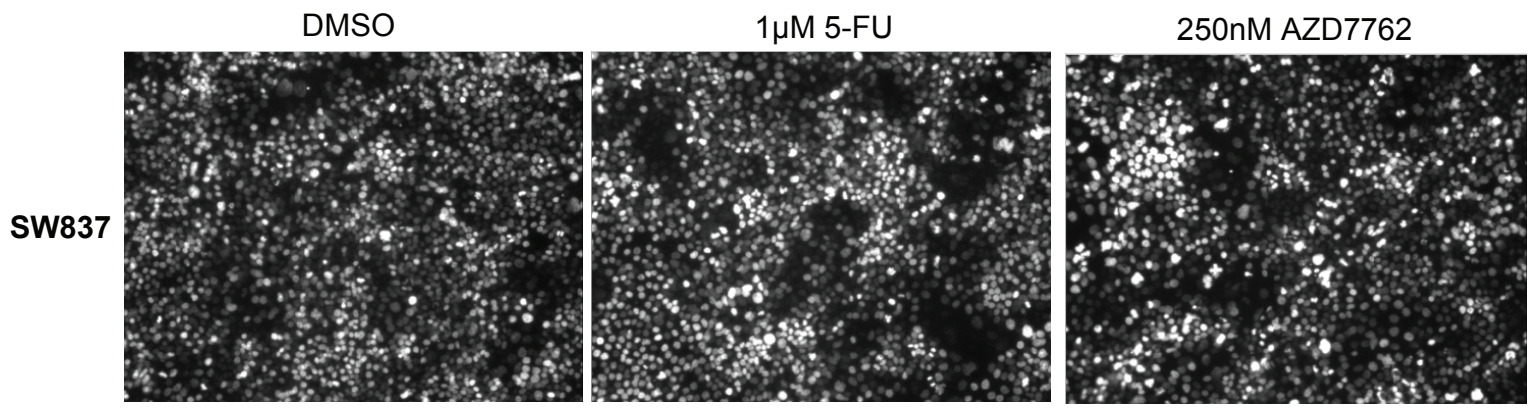

250nM AZD7762 + 1 $\mu \mathrm{M}$ 5-FU
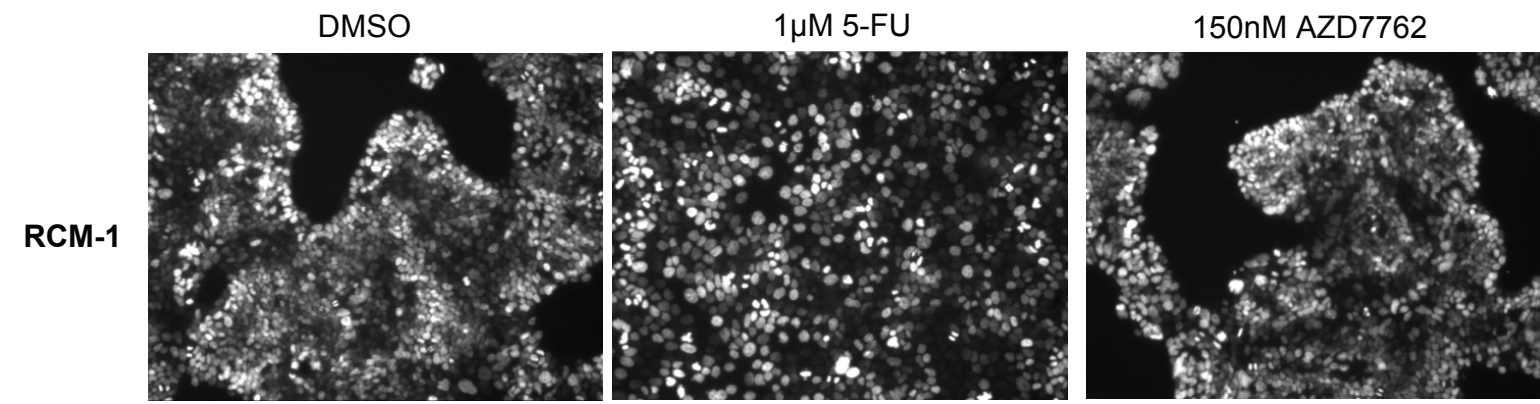

150nM AZD7762 + 1 $\mu \mathrm{M}$ 5-FU
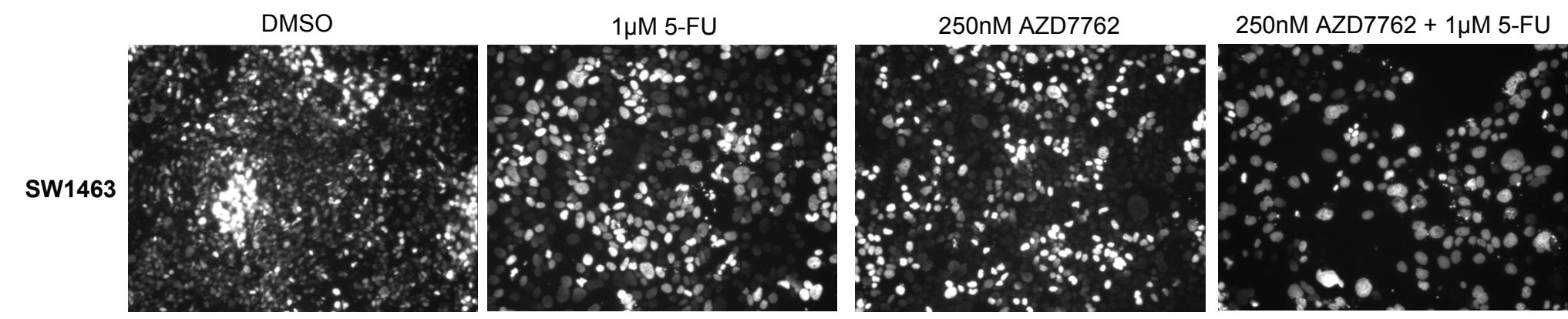